\title{
Kyrgyz Customary Law Development
}

\author{
Gulsara Kuldysheva1 ${ }^{1}$, Sovetbek Minbaev¹, Shailoobek Paraidinuulu¹, Aigul Mirzaeva², \\ Aktilek Atantaev1, Mamazakirov Rustam², Kuldyshev Amanbek ${ }^{3}$, Zhypargul Abdullaeva ${ }^{4}$ (i), \\ Elnura Toktobaeva ${ }^{1}$
}

\author{
${ }^{1}$ Department of the Theory and History of Government and Law, Osh State University, Osh, Kyrgyzstan \\ ${ }^{2}$ Department of the Civil Law and Procedure, Osh State University, Osh, Kyrgyzstan \\ ${ }^{3}$ Institute of Political Law Research, National Academy of Sciences, Bishkek, Kyrgyzstan \\ ${ }^{4}$ Science and Research Department, Osh State University, Osh, Kyrgyzstan \\ Email: ^jypar.science@oshsu.kg
}

How to cite this paper: Kuldysheva, G., Minbaev, S., Paraidinuulu, S., Mirzaeva, A., Atantaev, A., Rustam, M., Amanbek, K., Abdullaeva, Z., \& Toktobaeva, E. (2021). Kyrgyz Customary Law Development. Open Journal of Social Sciences, 9, 321-327. https://doi.org/10.4236/jss.2021.91023

Received: December 4, 2020

Accepted: January 23, 2021

Published: January 26, 2021

Copyright $\odot 2021$ by author(s) and Scientific Research Publishing Inc. This work is licensed under the Creative Commons Attribution International License (CC BY 4.0).

http://creativecommons.org/licenses/by/4.0/

\begin{abstract}
This article focuses on the formation and development of customary law in Kyrgyz society. The degree of customs, traditions, and legal systems created existing outside, and had significance on their basis, significantly higher than those of societies functioning within the framework of public education. The set of measures formed over time, which were focused on regulation of all aspects in the traditional Kyrgyz community life, represented by a large number of mutually independent tribes and clans, as a highly effective system capable of maintaining normal conditions of existence.
\end{abstract}

\section{Keywords}

Customary Law, Traditional Society, Legal Phenomenon, Legal Custom, Common Rules

\section{Introduction}

Customary law functioned for a long period since the national and ethnic unity of the Kyrgyz people was not established yet. At the fundamental level, customary law is regarded as representing the old social order (Bennett \& Vermeulen, 2009). Due to the fact, that Kyrgyz society consisted of isolated tribes, social relations taking place in them were characterized as a complex. The system of norms in the Kyrgyz society replaced by entire legal field, in fact, such a system was not possible for division, the context of preventing conditions facilitating the commission of specific offenses increased stability of the customary law in Kyrgyz society. Customary law, which is based on habits, as a legal phenomenon dominated in the legal Kyrgyz society sphere until the establishment of the So- 
viet Republic (Vladimirov, 2010).

Custom is a peculiar phenomenon that represents the combined experience of previous human communities, passing from generation to generation. In a large encyclopedic dictionary, the custom is defined as a mode of behavior, evolving into certain stereotypes in the process of a person's historical development, and emitting unified actions performed by a large number of people over a long period while maintaining the content and form of such actions unchanged (Prokhorov, 1998). Compared with other social phenomena, customs characterized by the existence of obligatory attributes as continuity in the historical sense, resistance to any side effects, credibility, applicability, and regularity, etc. Becoming the norms of customary law, customs formed during a long historical, centuriesold period when the established rules of behavior could be repeatedly transferred as a legacy to descendants, and their permanent habits (Mukambaeva, 2004).

Research reason is related to concept, essence and content of the customary law, interaction of which with official law have not been properly developed in the studies of legal scholars in Kyrgyzstan. In addition, customs have not been properly reflected as a source of law, either in legislative or in law enforcement practice in the modern legal system of the Kyrgyz Republic. At the same time, there is an objective need for a new assessment of the role and place of customary law in the Kyrgyz legal system. Therefore, we believe that it is necessary to realize the significance of fact in which the Kyrgyz customary law is a stable component of the legal development in our society. The study of the Kyrgyz customary law provides an opportunity to show the evolution of the legal system in Kyrgyzstan.

Research problem in this study is based on the certain omissions in the historical development of our government. According to our opinion, it is necessary to properly study the customary law development in the pre-Soviet period, to conduct a deep analysis of causes and factors that changed customary law. The relevance in this article is the fact that the Kyrgyz customary law is not only a legal phenomenon, but also our spiritual heritage. We consider that the above circumstances give particular urgency to the study of the customary law in Kyrgyzstan.

\section{Kyrgyz Society Development}

The Kyrgyz traditional community functioned as completely economically independent and therefore characterized as a closed society. Civil society is defined as organizations that exist between the family level and the government and which have a degree of autonomy from the state and the market (Giffen et al., 2005; Toogood-Luehrs, 2010). The peculiarity conditions of the socio-economic life in that times created such a strong type of person, not representing other living conditions, and non-observance of traditions was seen as scrapping of life guidelines and moral values. Principles of life activity applied for both, society and its members. In this regard, traditional Kyrgyz society, as a whole and specific rep- 
resentative is expressing non-adherence to any changes in life, as it is perceived as a destructive element of society.

This demonstrates the conservative nature of traditional society, which is objectively negative in relation to any innovations in its society. This condition was the reason why the formation of criminal law in Kyrgyzstan in a historical context should be interpreted in terms of transformation. At the same time, it should be noted that this process took place, first of all, under the influence of external factors, and not because of urgent internal needs.

We believe that one of the important specific features in the historical development of the Kyrgyz society is that most of it proceeded outside the framework of state education, while the form of state coexistence was inherent. It is generally recognized that in societies that exist outside the forms of the state, the degree of significance of customs and traditions, and the legal systems created on their basis, is significantly higher than those of societies functioning within the framework of public education. Moreover, the value of customs and traditions reaches its absolute character, taking into account the circumstances of the small number of nomadic tribal associations that existed relatively recently among the Kyrgyz ethnic group, as it acted as a guarantor of their sustainability. This was the reason that customs and traditions acted not only as a binding and strengthening factor for the clans and tribes in the Kyrgyz society, but rather performed essentially mental role. The Kyrgyz communities were located in large spaces, with various difficult terrains, which led to the maintenance of autonomy in them in full, both economically and politically.

\section{Kyrgyz Customary Law}

Mutual relations were mostly random, which, taking into account the described conditions and circumstances, predetermined the peculiarity of the process of formation and development of Kyrgyz customary law, including all its rules, which were generally identical, with some differences only. This came from an identical way of life, co-management, a single dialect, common historical development, encompassing the process of uniting clans and tribes to resist external invasion.

Kyrgyz Customary law influence application and implementation of recently reformed legal rules on the land rights, dispute solutions, and influences on the villagers value the written law (Giovarelli \& Akmatova, 2002).

It is necessary to emphasize the fact that the customary law of some clans and tribes was strongly influenced by the legal culture of the neighboring nations. Over the entire period of development, most of all were influenced in this aspect by the Kyrgyz tribes and tribes settled in the southern regions of Kyrgyzstan, who adopted Islamic justice based on Sharia, when a large number of Kyrgyz tribes and tribes based on customary law (adat).

Thus, in the period up to the entry of the Kyrgyz clans and tribes into the Russian Empire and during their stay as part of the empire, the Kyrgyz local courts 
applied their norm activities for two parallel systems of law common (adat) and Muslim (sharia) (Kostenko, 1880).

Nevertheless, it was started from the period of crowding out this kind of legal proceedings from Kyrgyz clans and tribes. The process of the adat foundation started from the depth of centuries, formed by the Kyrgyz as a legal system in the period of early feudalism (Brenner, 1990). Later, when Kyrgyz traditional society began to decompose, the norms of the adat gradually adapted to the interests of the feudal nobility, represented by both the manaps and the biys. At all stages of its development, Kyrgyz customary law was a closed legal system aimed at meeting the interests of a small part of the society with a nomadic lifestyle and in this connection, it objectively had a very low potential in the process of its evolutionary development up to its limit. The achievement of it led to the containment of further development of society. Kyrgyzstan redefined its governance by a comprehensive legal framework regulating land pasture management after independence in 1991, which was followed by development of Agrarian Policy Concept of the Kyrgyz Republic according to the Kyrgyzstan's Ministry of Agriculture in 2004; emphasizing importance of strengthening the agricultural advisory and introducing a more sustainable system of pasture management (Jepsen et al., 2017).

"Collection of Kyrgyz Customary Law" by the Russian political leader K.K. Palen conducted a study of customary law features of the Kyrgyz stage in the $19^{\text {th }}-20^{\text {th }}$ centuries (Palen, 1396). This compendium consists of three parts including 264 articles. The first part reflects the sections covering family relations, the second part is represented by the sections relating to the will and inheritance, the third part includes two sections, the first of which covers general issues, and the second regulates property and business issues. Thus, it can be argued that "Compendium" does not cover the entire volume of regulatory prescriptions of that period of Kyrgyz society. For example, it does not reflect criminal law issues when such norms occurred among neighboring peoples, in particular, Kazakhs contained criminal law norms contained in the legal code of the adat "Zhety-Zhargy" (Abdrasulov \& Gubaidullin, 2018), which by its content has similarities with Kyrgyz customary law shown in Figure 1 below.

In the legal code of the adat "Zhety-Zhargy" was a qualification of such types of acts as murder, beatings, mutilations, insults, theft, theft, non-compliance with the rules of filial piety, rape, adultery (Iskakov, 2007). In the Kyrgyz traditional society, given its legal system of all legal norms of criminal, family, civil and procedural nature, even during the dawn period, the entire system of legislation based on customary law was characterized by limited parameters. A serious factor influencing the perfection of the Kyrgyz legal system was the lack of a written language of the Kyrgyz clans and tribes, which directly acted as a natural obstacle to the accumulation of legal experience and its consolidation. The legal experience of that time was doomed to extinction since the only communicative means that was used in Kyrgyz society was an oral speech. This circumstance 


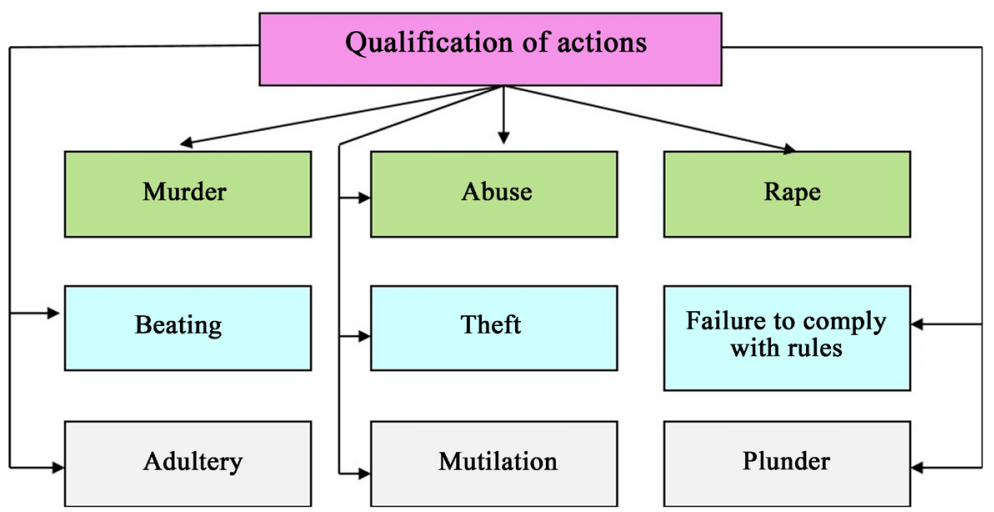

Figure 1. Qualification of actions in the vault of the adat "Zhety-Zhargy" (according to Abdrasulov \& Gubaidullin, 2018).

made it possible to preserve only the most stable, with basic regulatory features, elements of law enforcement practice, which in the conditions of a long mobile nomadic way of life could not contribute to a certain substantial improvement of the current Kyrgyz legal system.

\section{Kyrgyz Adat}

Also, another limiting factor in the expansion of the Kyrgyz adat is the lack of development of property relations. Well-known forms of ownership were present due to the element of power, used in specific conditions. Property is of paramount importance in society, only in the case when expressed in the form of personal property (Alekseev, 1981). Nomadic communities engaged in cattle breeding, whose labor productivity was low, because of the collective nature of labor activity, the main thrust of which was to ensure their vital needs. This led to a low degree of social disengagement in terms of a small excess product, and for this reason, patronizing relations prevailed in traditional Kyrgyz society. Such relations in scientific thought are interpreting as a way of regulating social relations based on genealogy, conservative views, and worldviews on family and everyday life.

In this context, patrimony reflects social realities, where the regulation of social relations is based on family clan relations, which in their content are determined by the organization of the production process through the socialized use of pasture and other works (Zhumaganbetov, 2004). Thus, the analysis of the above circumstances establishing the dominance of the public form of ownership in the traditional society of Kyrgyz clans and tribes. The family related or ancestral property, as the main form of social ownership of a traditional society with all its attendant deficiencies, objectively, for a long historical period, weakened the rate of the evolutionary development of Kyrgyz society and predetermined its characteristics, by having a natural impact on the society's legal side (Kuldysheva, 2010).

\section{Conclusion}

Above mentioned conditions are describing the essence of the Kyrgyz traditional 
society where the consequence of facts that customary law did not divide into civil law and criminal law. And most of all such rights had a characteristic feature, which was expressed in the absence of a verge of criminal offenses from civil offenses, that any crime was interpreted by customary law as a result of mutual relations between the parties. The value of customs and traditions characterized by taking into account the nomadic tribe associations. In this article, Kyrgyz customary law, society development, and adat category related to property were described.

\section{Conflicts of Interest}

The authors declare no conflicts of interest regarding the publication of this paper.

\section{References}

Abdrasulov, E. B., \& Gubaidullin, M. G. (2018). "Zhety-Zhargy" a Historical and Legal Monument of the Justice of the Kazakh Khanate. Science, New Technologies and Innovations of Kyrgyzstan, 8, 1-4.

Alekseev, S. S. (1981). General Theory of Law (Part 1, 25). Moscow: Yurid.

Bennett, T. W., \& Vermeulen, T. (2009). Codification of Customary Law. Journal of African Law, 24, 206-219. https://doi.org/10.1017/S0021855300009542

Brenner, R. (1990). Feudalism. In J. Eatwell, M. Milgate, \& P. Newman (Eds.), Marxian Economics. The New Palgrave (pp. 170-185). London: Palgrave Macmillan.

Giffen, J., Earle, L., \& Buxton, C. (2005). The Development of Civil Society in Central Asia. https://www.intrac.org/resources/development-civil-society-central-asia/

Giovarelli, R., \& Akmatova, C. (2002). Local Institutions That Enforce Customary Law in the Kyrgyz Republic and Their Impact on Women's Rights. Agriculture \& Rural Development e-paper, Washington DC: World Bank.

Iskakov, I. Z. (2007). Overview of the Criminal Law of Kazakhstan, Its Evolutionary Path from Customary Law to Codified Legislation. Lawyer, 7, 28.

Jepsen, F., Rota, A., Liversage, L., \& Chartier, M. L. H. (2017). Legal Reform, Governance and Natural Resource Management: The Kyrgyz Pasture Reform. Journal of Law and Rural Development: Land Governance, 1, 43-49.

Kostenko, L. F. (1880). Turkestan Territory, Experience of Military-Statistical Review of the Turkestan Military District (Part I, 12). Material for Geographic Statistics of Russia.

Kuldysheva, G. K. (2010). State Administration and Local Self-Government (Legal Regulation) (248 p). Bishkek.

Mukambaeva, G. A. (2004). Manas and Law(226 p). Bishkek.

Palen, K. K. (1396). Collection of Kyrgyz Customary Law. Fund, 1, 452, Archive of the Russian State Archives of St. Petersburg.

Prokhorov, A. M. (1998). The Big Encyclopedic Dictionary(829 p). Moscow: Big Russian Encyclopedia; St. Petersburg: Norint.

Toogood-Luehrs, K. (2010). Civil Society and Social Capital in Central Asia. In H. K. Anheier, \& S. Toepler (Eds.), International Encyclopedia of Civil Society. New York, NY: Springer.

Vladimirov, K. (2010). "Red East": Soviet Central Asia in the 1920s. Journal of Eurasian 
Studies, 1, 127-133. https://doi.org/10.1016/j.euras.2010.04.004

Zhumaganbetov, T. S. (2004). The Problems of Formation and Development of the Ancient Turkic System of Statehood and Law. The 6th-the 12th Centuries. Almaty: Zheti Zharghy. 